\title{
Amphibia, Anura, Strabomantidae, Pristimantis reichlei Padial and De la Riva, 2009: First record from Brazil, southwestern Amazonia
}

\author{
Paulo Roberto Melo-Sampaio ${ }^{1 *}$ and Moisés Barbosa de Souza ${ }^{2}$ \\ 1 Universidade Federal do Acre, Programa de Pós-Graduação em Ecologia e Manejo de Recursos Naturais, Laboratório de Herpetologia (HerPet). \\ CEP 69915-900. Rio Branco, AC, Brazil. \\ 2 Universidade Federal do Acre, Centro de Ciências Biológicas e da Natureza, Laboratório de Herpetologia (HerPet). CEP 69915-900. Rio Branco, \\ AC, Brazil \\ * Corresponding author. E-mail: herpeton@gmail.com
}

\begin{abstract}
Here we reported the presence of the strabomantid frog Pristimantis reichlei in the Brazilian territory. The distribution of this newly described species was expected to Brazil, however, no information was available so far. The diversity of species in this genus may be greater in Acre state, and we suggest that further studies be conducted to confirm this hypothesis.
\end{abstract}

Pristimantis is the largest genus of Neotropical vertebrates, with around 400 species (Hedges et al. 2008). The genus is part of Strabomantidae, a family of frogs with broad distribution in Honduras, Central America, Colombia, Ecuador, Peru, Bolivia, and Amazonian Brazil and the Guianas; Trinidad and Tobago; Grenada, Lesser Antilles (Hedges et al. 2008; Frost 2010). This group is most diverse in the eastern foothills of the Andes (Lynch and Duellman 1997; Hedges et al. 2008). Brazil is home to 27 species with widespread distributions in Amazonia (SBH 2009). Souza (2009) recorded 16 species of Pristimantis from Acre state (Parque Nacional da Serra do Divisor and Reserva Extrativista Alto Juruá) but the identities of some of those species remain uncertain.

On 06 November 2009, at ca. 20:45 h, PRMS and MBS collected an adult male Pristimantis reichlei (26.5 mm SVL) at Fazenda Experimental Catuaba, municipality of Senador Guiomard, state of Acre, Brazil (1004'56" S, 67³7’33” W; datum: WGS84; $183 \mathrm{~m}$ above sea level). The specimen was found on a tree branch about $0.5 \mathrm{~m}$ above ground. The predominant vegetation in the area is "tabocal" or open forest with Guadua weberbaueri bamboo as defined by Silveira (2005).

Although Pristimantis reichlei is a direct-development breeder, males were found at night calling in a chorus of several individuals. Because of its recent identification, this species is poorly known and for a long time was confused with other species of the $P$. unistrigatus group from southwestern Amazonia (Padial and De la Riva 2009).

The present note provides the first country record for Pristimantis reichlei in Brazil, and the northernmost record for the species, extending its known distribution ca. $805 \mathrm{~km}$ in direct line $\mathrm{N}$ from its type locality Rio Carrasco National Park, Provincia Chapare, Departamento Cochabamba, Bolivia (Padial and De la Riva 2009). The specimen collected (UFAC 4422) was deposited in the herpetological collection of the Universidade Federal do Acre, in Rio Branco, state of Acre.

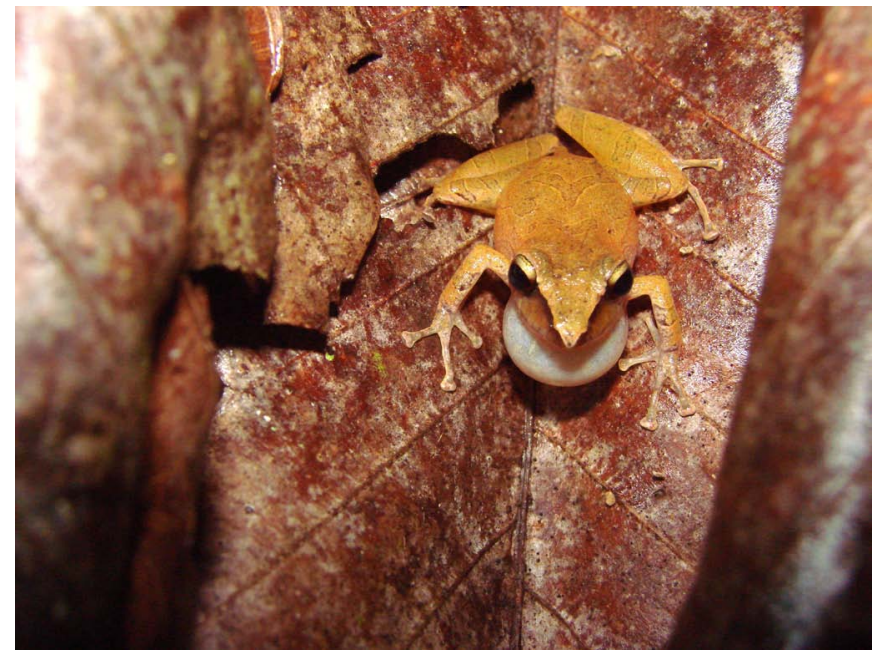

FIgURE 1. Live adult male Pristimantis reichlei (not collected) from municipality of Senador Guiomard, state of Acre, Brazil, showing vocal sac. Note that finger I is smaller than finger II. Photo P.R. Melo-Sampaio.

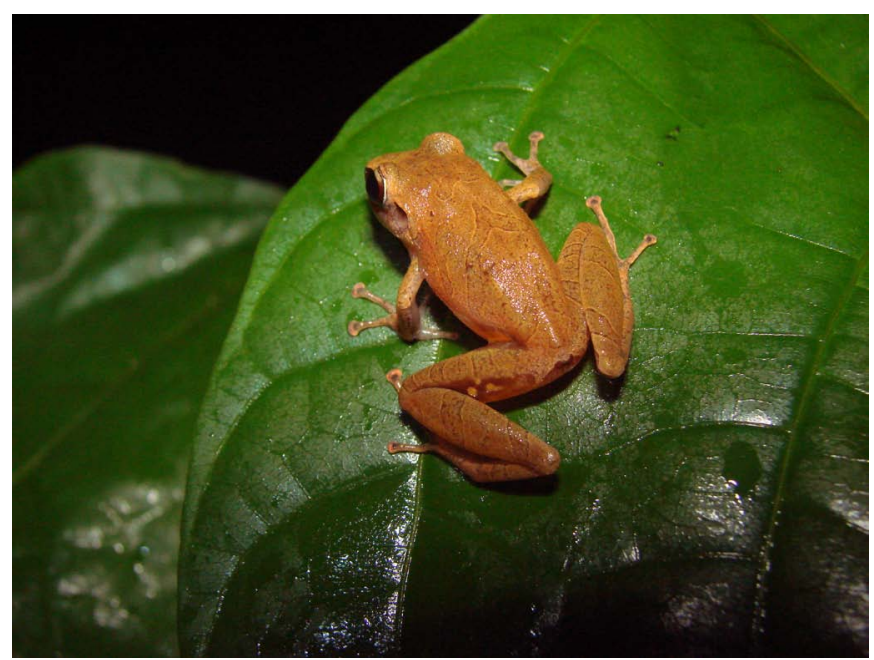

Figure 2. Male Pristimantis reichlei (not collected). Note the posterior surface of the thigh, with brown color and conspicuous orange spots. Photo: P.R. Melo-Sampaio. 


\section{Literature Cited}

Frost, Darrel R. 2010. Amphibian Species of the World: an Online Reference. Version 5.4 (8 April, 2010). Electronic Database accessible at http:// research.amnh.org/vz/herpetology/amphibia/ American Museum of Natural History, New York, USA.Captured on 27 May 2010.

Hedges S.B., W.E. Duellman and S.B. Heinicke. 2008. New World direct-developing frogs (Anura: Terrarana): Molecular phylogeny, classification, biogeography, and conservation. Zootaxa 1737: 1-182.

Lynch J.D. and W.E. Duellman. 1997. Frogs of the genus Eleutherodactylus (Leptodactylidae) in Western Ecuador: Systematics, Ecology, and Biogeography. University of Kansas Special Publication 23: 1-236.

Padial, J.M. and I. De la Riva. 2009. Integrative taxonomy reveals cryptic Amazonian species of Pristimantis (Anura: Strabomantidae). Zoological Journal of the Linnean Society 155: 97-122.
Silveira, M. 2005. A floresta aberta com bambu no sudoeste da Amazônia: padrões e processos em múltiplas escalas. Rio Branco: Edufac. 157 p.

Souza, M.B. 2009. Anfíbios: Reserva Extrativista do Alto Juruá e Parque Nacional da Serra do Divisor, Acre. Campinas: IFCH. 77 p.

SBH. 2009. Brazilian amphibians - List of species. Electronic database accessible at http://www.sbherpetologia.org.br. Sociedade Brasileira de Herpetologia. Captured on 06 December 2009.

RECEIVED: May 2010

REVISED: June 2010

ACCEPTED: July 2010

Published Online: August 2010

EDITORIAL RESPONSIBILITY: Marcelo N. de C. Kokubum 